\title{
Anne Lancashire and David J. Parkinson (eds). Civic London to 1558. 3 vols. Cambridge: Records of Early English Drama/D.S. Brewer, 2015. Pp 1795.
}

TRACEY HILL

Bath Spa University
Early Theatre 19.1 (2016), 151-3

http://dx.doi.org/10.12745/et.19.1.2906

It is, I suppose, a cliché of book reviewing to begin by describing the work in question as 'long-awaited' but in the case of REED's massive and beautifully presented Civic London trilogy the cliché is absolutely true. Through its publication of over twenty previous volumes on provincial and regional theatre (some sadly now out of print), REED has a justified reputation as one of the prime resources for the study of early drama in its various manifestations. The London records have long been a gap, albeit a daunting one, in REED's œuvre. Civic London has thus been a considerable time in the making and one only has to read Anne Lancashire's acknowledgements (a number of which are to 'late' colleagues) to get a sense of a life's work finally coming to fruition.

It is also something of a cliché to call a work 'magisterial' but for a threevolume publication that weighs in at almost 1800 pages there is no other suitable word. The last three-volume set produced by the REED project team was on the Inns of Court from ca 1400 to 1642, edited by Alan Nelson and John Elliott in 2011; although of course the topographic locations overlap to an extent, Civic London is of another magnitude altogether, both in terms of its enormous chronological scope from the thirteenth to the sixteenth centuries, and also for the sheer diversity of theatrical and musical performance history it encompasses. Two of the volumes comprise the actual records: volume 1 covers $1286-7$ to $1520-3$, and volume 2 (as a tangible reflection of the substantial rise in dramatic forms in the sixteenth century) 1521-2 to 1558. The third book provides translations of the early English, Latin, and Anglo-French entries (for which Abigail Ann Young was primarily responsible), end-notes, and glossaries. There are a handful of illustrations, two neatly drawn maps showing performance venues and City ward boundaries, a full and wonderfully illuminating introduction to the historical and cultural contexts of the records, written in Lancashire's characteristically circumspect idiom, and a series of appendices containing material tangential to the main records such as short biographical notes on named individuals such as minstrels, an overview of saints' days and festivals, and a list of mayors and sheriffs throughout the whole period under scrutiny. Where the civic record no longer survives, or is partial, the editors have mined chronicle histories for information about performances and entertainments. The overall intention is to provide as 
much explanatory framework as possible, and accordingly volume 1 discusses the various processional routes, the nature of the pageantry employed on ceremonial occasions, the use of music and actors, and so on.

Handsome though they undoubtedly are, these are not books to be admired but to be used. It almost goes without saying that collectively they form a quite stupendous resource. As with visiting a physical archive, one has first to understand the remit of these volumes as well as the original function of the records they contain, and to learn to navigate the City's bureaucratic and quite ritualistic language. It would be brave indeed simply to dive into the records. Lancashire and her collaborators have done a fine job of orientating the reader: the introduction outlines the various civic roles at play and carefully explains how the City's governmental structures had an impact on its culture; and the numerous glossaries aid the reader in interpreting as well as situating the records, the meaning of which might otherwise be sometimes opaque (the general reader is unlikely to know offhand what a 'cresset' or a 'targett' is, for instance). The full gamut of the civic archive - the City Corporation, its constituent guilds/ livery companies 'Great' and small, and the Bridge House — has been forensically excavated. Indeed, such completism can appear intimidating at first. I would therefore encourage the reader of these volumes to use the appendices (especially the invaluable chronological survey) and the superbly useful index in tandem with the records as Lancashire and her collaborators intended. The bias in the volumes is (understandably) historical, although despite the copious number of secondary sources cited there is a relative absence of literary treatments of civic theatricality beyond a brief reference to Lawrence Manley's work. There is just the occasional minor niggle, which in such an enormous undertaking is probably inevitable: Lancashire does not appear to be aware, for instance, that Middleton's 'commission' to write entertainments in the early 1620s was not ad hoc but part of his formal role as city chronologer (liv). These are minor issues, though, and they do not detract in any significant way from the achievement of these volumes.

Civic London does convey information that transcends local detail, though. Fascinating as the individual entries are, they don't always seem on the surface to amount to much: what is one to glean from a passing line in the 1556 Pewterers' memorandum book detailing the purchase of silken trumpet banners, one might wonder? Taken together, however, these fragments do comprise a kind of narrative; in particular, one can see across this large sweep of time the emergence of professional, secular drama out of its medieval religious traditions. 1558, the end point of these volumes, also stands as a moment just before the annual mayoral inauguration took on its fully fledged form. As a whole, these collated records 
will surely facilitate further, more discursive research on the development of civic culture over time and in the context of tremendous social, demographic, and religious change. A vivid picture emerges too of a city that took culture very seriously and devoted considerable resources to its realization: Philip of Spain's arrival in London in 1553, as an example, was accompanied by a pageant 'at the Condyt [conduit] in Gracechurche streate', 'singing and playinge by the peryshe [parish] clerkes and chyldern' 'at saynte margaretes Churche in newe fyshestrete', numerous other pageant stations, and a requirement that 'the Stockes [Market] [be] goodely hanged with ryche hangynges' (2.784). As these instances show, the REED team's transcription of the records is at pains to capture all forms of 'theatre' in this period, not just scripted plays performed with actors in established venues, but anything that drew an audience and which has left archival traces, including bear-baiting and the 'rough music' prescribed as part of legal punishments.

The underlying message of Civic London, then, is that London was throughout this long period of time an intensely theatrical space, not the dourly mercantile realm peopled with the anti-theatrical 'puritans' of misinformed popular opinion. Its citizens could experience entertainments ranging from grandiose ceremonial royal entries to the torchlit Midsummer Watch processions to pious play-lets performed at Clerkenwell to ephemeral entertainments in company halls. One learns with delight that in sixteenth-century London the Christmas season stretched from 31 October to 2 February, and that yes, on occasion the city conduits did run with wine. REED's stated aspiration that these volumes will 'allow scholars to analyze relationships amongst the city's various hierarchies of power - royal, noble, mercantile, ecclesiastical, artistic, educational, and civic' has been truly realized. ${ }^{1}$ Medievalists, musicologists, Reformation scholars, theatre historians all will find riches here, and I, for one, cannot wait for Civic London from 1558 to appear.

\section{Notes}

1 'Forthcoming: Civic London to 1558', REED. http://reed.utoronto.ca/print-collections -2 /forthcoming/ 